\title{
Repellent and Oviposition-Deterring Activity of Rosemary and Sweet Marjoram on the Spider Mites Tetranychus urticae and Eutetranychus orientalis (Acari: Tetranychidae)
}

\author{
S. A. A. AMER ${ }^{1}$, A. M. REFAAT ${ }^{2}$ and F. M. MOMEN 1 \\ 1Plant Protection Department, 2Pharmacology Science Department, \\ National Research Center, Dokki, Cairo, Egypt
}

\begin{abstract}
The deterrent and toxic effect of two essential oils, Majorana hortensis. Moench and Rosmarinus officinalis L. on the two tetranychid mites Tetranychus urticae Koch and Eutetranychus orientalis (Klein) were studied under laboratory conditions. Both materials used were more potent for E. orientalis than against $T$. urticae with a significant increase in repellency.

Leaf discs treated with increasing concentrations of the two oils showed increased mortality of both spider mites and reduction in the total numbers of eggs laid. This result could be due to the oil of the higher oxygenated compounds content that was more effective in this respect.
\end{abstract}

Keywords: Tetranychus urticae, Eutetranychus orientalis, Majorana hortensis, Rosmarinus officinalis, essential oil.

The use of chemical pesticides offers problems such as atmospheric pollution and residual toxicity in food. For these reasons, research on non-contaminating pesticides is needed. Research in recent years has been turning more towards selective biorational pesticides, such as plant-derived compounds, because they are perceived to be safer than the synthetics (Arnason et al., 1989). Few studies have been done on such plants having acaricidal influences are assumed to be acceptable because they are alterable in nature (Schauer and Schmutterer, 1981; Amer 1984; Rasmy 1985; Amer et al., 1989; Dimetry et al., 1990). Among these botanicals, the essential oils exhibit antifeedant activity and toxic to some important insects (Sy et al., 1972; Purohit et al., 1983; Don-Pedro, 1985; Tare and Sharma, 1988).

In Egypt, very few research has been reported on the effect of the essential oils on mites (Amer et al., 1993; Ibrahim et al., 1993; El-Gengaihi et al., 1996).

Both Majorana hortensis Moench and Rosmarinus officinalis L. (Fam. Labiatae) are considered as two of the most valuable aromatic and medicinal plants. Rosemary oil has been reported by Guenther (1961) as an insect repellent, and as an ingredient in rubefacient liniments. He stated also that its oil contains: $\alpha$-pinene, camphene, cineole, dipentene, camphor, borneol and sesquiterpene compounds. Sweet marjoram is used medicinally as carminative and stimulant due to its strong, highly aromatic and pleasing odor (Guenther, 1961). Marjoram oil contains terpinene 4-01, $\alpha$-terpinene, D-limonene, linalool, linalyl acetate, P-cymene, $\beta$-pinene and $\alpha$-terpineol. 
This is the first report, dealing with the acaricidal properties and biological activity of both $M$. hortensis and $R$. officinalis on two of the most serious pests in Egypt, namely Tetranychus urticae Koch and Eutetranychus orientalis (Klein) under laboratory condition.

\section{Materials and Methods}

\section{Plant materials}

Both plants essential oils (rosemary and sweet marjoram) were obtained in June and November 1998, respectively from the air-dried herbs about seven to nine months old, originally grown as plants in the Experimental Farm of National Research Center at Giza.

\section{Preparation of the oil}

The essential oil was extracted by submitting the air-dried herb of each to stem distillation for 3 hours in a Clevenger apparatus. The oil collected from each was dehydrated over anhydrous sodium sulfate and subjected to GC-MS analysis.

\section{Chromatographic investigation of the volatile oil}

The obtained essential oils were subjected for GC-MS analysis under the following conditions:

GC-MS Finnigan mat SSO 7000 Digital DEC 3000. Work station: Digital DEC 3000. Ionization mode Eleven 70. Column: Capillary column of Fused silica, DB-5 (5\% phenyl), $30 \mathrm{~m}$ length, $0.32 \mathrm{~mm}$ i.d and $0.25 \mu \mathrm{m}$ thickness. Carrier gas: Helium at $13 \mathrm{psi}$. Temperature-programming: initial temp. $60{ }^{\circ} \mathrm{C}$ for $15 \mathrm{~min}, 60-220^{\circ} \mathrm{C}$, at a rate of $5{ }^{\circ} \mathrm{C} /$ min., final temp. $250^{\circ} \mathrm{C}$ for $15 \mathrm{~min}$., ionization voltage: $70 \mathrm{eV}$. The identification of the compounds was based on comparison of the retention times and mass spectra with corresponding data components of references oils and pure compounds whenever possible. Mass spectra were compared with those of the published data by Adams (1989). Qualitative determination was based on peak area measurements.

\section{Preparation of the emulsions}

Emulsions of rosemary (R. officinalis L.) and sweet marjoram (M. hortensis Moench) were prepared respectively by mixing five drops of Triton-X 100 emulsifier with $2 \mathrm{ml}$ of oil plus an amount of water to obtain $2 \%$ concentration of the oil emulsion. A series of dilution i.e. $1,0.5,0.25$ and $0.125 \%$ were prepared from the stock $2 \%$ solution using water.

\section{Maintenance of mite stock cultures}

The stock cultures of two spotted spider mite $T$. urticae were collected from infested lima bean (Phaseolus vulgaris L.) in the laboratory at N.R.C. Cairo. The citrus brown mite, E. orientalis, was obtained from cultures maintained on sweet potato. The mites were reared in a controlled climate room at $25-27^{\circ} \mathrm{C}$ and $60 \pm 5 \%$ R.H. 
Pots of lima bean seedlings cultivated in soil were placed in center of the cage (measured $70 \times 40 \times 60 \mathrm{~cm}$ ). A continuous light source of (60 watt) flourcent was provided. Large numbers of $T$. urticae were placed on leaf of the lima bean.

\section{Treatment}

REPELLENCY TEST PROCEDURE FOR ADULT FEMALES OF T. URTICAE AND E. ORIENTALIS

Raspberry leaf discs were placed with the lower surface upwards in petri-dish lined with moist cotton wool. Half of each disc was painted with the proper concentration, while the other half treated with water only. Adult females were placed on the midrib and observations on repellency and oviposition were taken after 24, 48 and $72 \mathrm{~h}$, respectively. Each treatment comprised 5 replicates, each replicate contained 10 females. The repellency (mites which had left the discs were considered as repelled) was calculated according to Lwande et al. (1985).

\section{TOXICITY AND BIOLOGICAL EFFECTS OF ROSEMARY AND SWEET MARJORAM ON ADULT} FEMALES OF T. URTICAE AND E. ORIENTALIS

Adult females of the same age of both species were placed individually on raspberry leaf discs treated with different concentrations of both oils. Twenty replicate leaf discs were used and a similar number of discs treated with water only as control. The total number of eggs laid on the treated discs were recorded over a period of 10 days. The mortality of both tetranychid mites was also recorded.

All the experiments reported herein were carried out in the laboratory at $27 \pm 2{ }^{\circ} \mathrm{C}$ and 70-75\% R.H.

Statistical analyses were carried out by using "F" test .

\section{Results and Discussion}

\section{Chemical constituents of rosemary and sweet marjoram oils}

GC-MS and GLC analysis of $R$. officinalis and M. hortesis essential oils, detected the presence of the following compounds:

1. Hydrocarbon terpenes.

2. Oxygenated terpenes.

3. Hydrocarbon sesquiterpenes.

4. Oxygenated sesquiterpenes.

One can see in Tables 1, 2, 3 and Figs. 1, 2 the identification of forty-four components which represent about $90.5 \%$ of the total rosemary oil. The oil is characterized by the dominant occurrence of oxygenated hydrocarbon terpenes which contributed with $79.922 \%$ of oil content. As assessed from the total peak area, cineole represented the major compound (ca $22 \%$ ), followed by camphor $(9.77 \%$ ) and linalool $(5.01 \%)$. The same tables indicated also that the oxygenated sesquiterpenes represented the least content value $(2.94 \%)$ only. 
Table 1

The content of the terpene hydrocarbon compounds in sweet marjoram and rosemary oils

\begin{tabular}{|c|c|c|c|c|c|}
\hline \multicolumn{3}{|c|}{ Sweet marjoram oil } & \multicolumn{3}{|c|}{ Rosemary oil } \\
\hline Peak No. & Compounds & $\%$ & Peak No. & Compounds & $\%$ \\
\hline 1 & Tricyclene & 0.003 & 1 & $\alpha$-Pinene & 5.006 \\
\hline 2 & $\alpha$-Thujene & 2.054 & 2 & Camphene & 1.886 \\
\hline 3 & $\alpha$-Pinene & 1.126 & 3 & $\beta$-Pinene & 0.526 \\
\hline 4 & Camphene & 0.046 & 4 & Myrecene & 1.762 \\
\hline 5 & Sabinene $+\beta$-Pinene & 13.999 & 5 & 2-Carene & 1.500 \\
\hline 6 & Myrecene & 1.251 & 6 & $\beta$-Phellandrene & 0.168 \\
\hline 7 & $\alpha$-Phyllendrene & 0.574 & 8 & $\gamma$-Terpinene & 0.516 \\
\hline 8 & 3-Carene & 0.499 & 9 & Terpinolene & 0.700 \\
\hline 9 & $\alpha$-Terpinene & 2.260 & & Unknown & 1.128 \\
\hline 10 & p-Cymene & 7.802 & & Total & 13.192 \\
\hline 11 & Limonene & 1.778 & & & \\
\hline \multirow[t]{3}{*}{12} & $\gamma$-Terpinene & 21.456 & & & \\
\hline & Unknown & 0.035 & & & \\
\hline & Total & 52.883 & & & \\
\hline
\end{tabular}

Table 2

The content of the oxygenated terpene compounds in sweet marjoram and rosemary oils

\begin{tabular}{|c|c|c|c|c|c|}
\hline \multicolumn{3}{|c|}{ Sweet marjoram oil } & \multicolumn{3}{|c|}{ Rosemary oil } \\
\hline Peak No. & Compounds & $\%$ & Peak No. & Compounds & $\%$ \\
\hline 13 & cis-p-Menth-2-en-1-ol & 1.040 & 7 & Cineole & 21.957 \\
\hline 14 & Terpinolene & 0.692 & 10 & Fenchone & 0.260 \\
\hline 15 & trans-p-Menth-2-en-1-ol & 3.054 & 11 & Linalool & 7.433 \\
\hline 16 & Linalool & 0.566 & 12 & Camphor & 9.771 \\
\hline 17 & cis-Sabinene hydrate & 0.241 & 13 & Isoborneol & 6.009 \\
\hline 18 & Citronellal & 4.624 & 14 & Borneol & 6.915 \\
\hline 19 & Borneol & 0.711 & 15 & Terpinene-4-ol & 0.120 \\
\hline 20 & Terpinene-4-ol & 8.246 & 16 & $\alpha$-Terpineol & 6.402 \\
\hline 21 & $\alpha$-Terpineol & 6.196 & 17 & Verbenone & 7.133 \\
\hline 22 & Nerol & 0.293 & 18 & new-iso-Dihydro carveol & 1.220 \\
\hline 23 & Linalyl acetate & 1.836 & 19 & cis-Myrtanol & 1.901 \\
\hline 24 & Bornyl acetate & 0.212 & 20 & Carvone oxide & 0.266 \\
\hline 25 & Isomenthyl acetate & 2.869 & 21 & Bornyl acetate & 2.600 \\
\hline 26 & trans-Carvyl acetate & 0.170 & 22 & Carvacrol & 0.038 \\
\hline 27 & Terpinenyl acetate & 0.014 & 24 & Eugenol & 0.215 \\
\hline 28 & Neryl acetate & 0.308 & 25 & cis-Carvyl acetate & 0.189 \\
\hline \multirow[t]{4}{*}{30} & Geranyl acetate & 0.413 & 28 & Methyl eugenol & 0.271 \\
\hline & Unknown & 4.996 & 30 & Geranyl acetate & 0.617 \\
\hline & Total & 36.48 & & Unknown & 6.618 \\
\hline & & & & Total & 79.922 \\
\hline
\end{tabular}


Table 3

The content of sesquiterpene compounds in sweet marjoram and rosemary oils

\begin{tabular}{|c|c|c|c|c|c|}
\hline \multicolumn{3}{|c|}{ Sweet marjoram oil } & \multicolumn{3}{|c|}{ Rosemary oil } \\
\hline Peak No. & Compounds & $\%$ & Peak No. & Compounds & $\%$ \\
\hline \multicolumn{6}{|c|}{ I-Sesquiterpene hydrocarbon compounds } \\
\hline 29 & $\alpha$-Copaene & 0.005 & 23 & D-Elemene & 0.113 \\
\hline 31 & $\beta$-Bourbonene & 0.016 & 26 & $\alpha$-Copaene & 0.132 \\
\hline 32 & $\beta$-Cubebene & 0.025 & 27 & $\beta$-Elemene & 0.034 \\
\hline 33 & $\beta$-Caryophyllene & 3.981 & 29 & $\beta$-Caryophyllene & 2.170 \\
\hline 34 & Aromadendrene & 0.104 & 31 & $\alpha$-Humulene & 0.453 \\
\hline 35 & $\alpha$-Humulene & 0.279 & 32 & $\gamma$-Muurolene & 0.179 \\
\hline 36 & Germacrene-D & 0.021 & 33 & Germacrene-B & 0.065 \\
\hline 37 & $\beta$-Bisabolene & 2.914 & 34 & $\alpha$-Longipinene & 0.117 \\
\hline 38 & $\gamma$-Cadinene & 0.019 & 35 & $\beta$-Bisabolene & 0.090 \\
\hline \multirow[t]{6}{*}{39} & trans- $\gamma$-Bisabolene & 0.021 & 36 & $\gamma$-Cadinene & 0.334 \\
\hline & Unknown & 0.642 & 37 & Calaminene & 0.031 \\
\hline & Total & 8.027 & 38 & Trans- $\boldsymbol{\gamma}$-Bisabolene & 0.053 \\
\hline & & & & Unknown & 0.680 \\
\hline & & & & Total & 4.451 \\
\hline & \multicolumn{5}{|c|}{ II-Oxygenated sesquiterpene compounds } \\
\hline 40 & Germacrene-4-ol & 0.028 & 39 & Nerolidol & 0.013 \\
\hline 41 & Spathulenol+Caryophyllene oxide & 1.048 & 40 & Spathulenol & 0.597 \\
\hline 42 & Globulol & 0.150 & 41 & Caryophyllene oxide & 0.036 \\
\hline 43 & Viridiflorol & 0.140 & 42 & Tau-Cadinol & 0.194 \\
\hline 44 & Tau-Cadinol & 0.138 & 43 & $\alpha$-Cadinol & 0.271 \\
\hline 45 & $\alpha$-Cadinol & 0.043 & 44 & Epi- $\alpha$-Bisabolol & 0.215 \\
\hline \multirow[t]{3}{*}{46} & Epi- $\alpha$-Bisabolol & 0.003 & & Unknown & 1.109 \\
\hline & Unknown & 1.061 & & Total & 2.435 \\
\hline & Total & 2.610 & & & \\
\hline
\end{tabular}

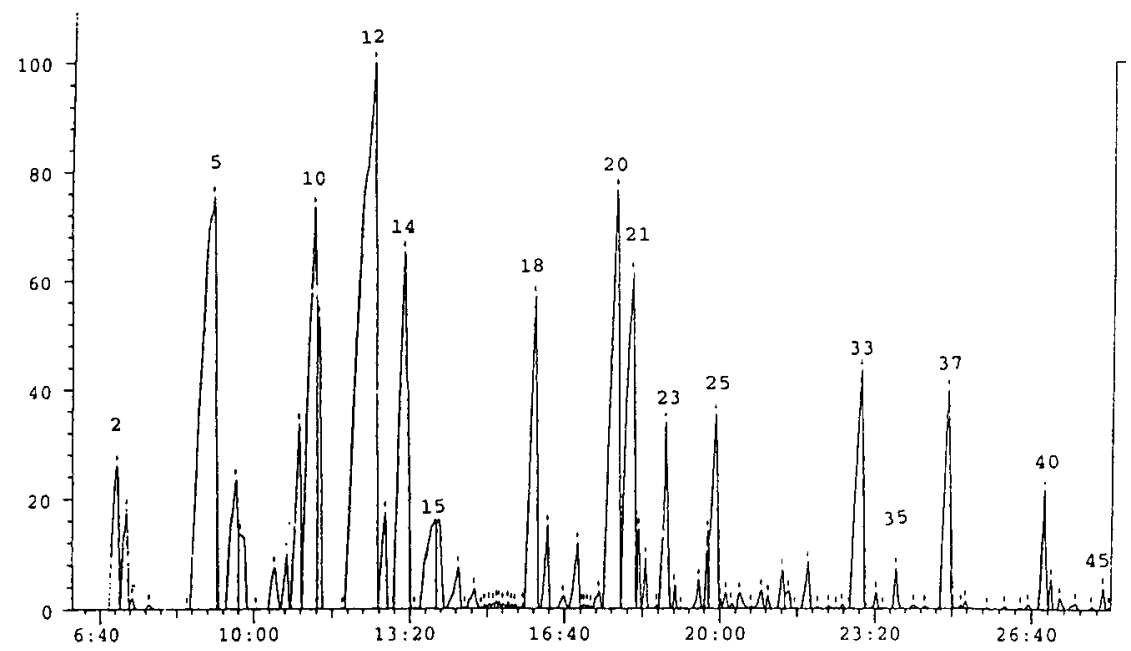

Fig. 1. Chromatogram of marjoram oil 


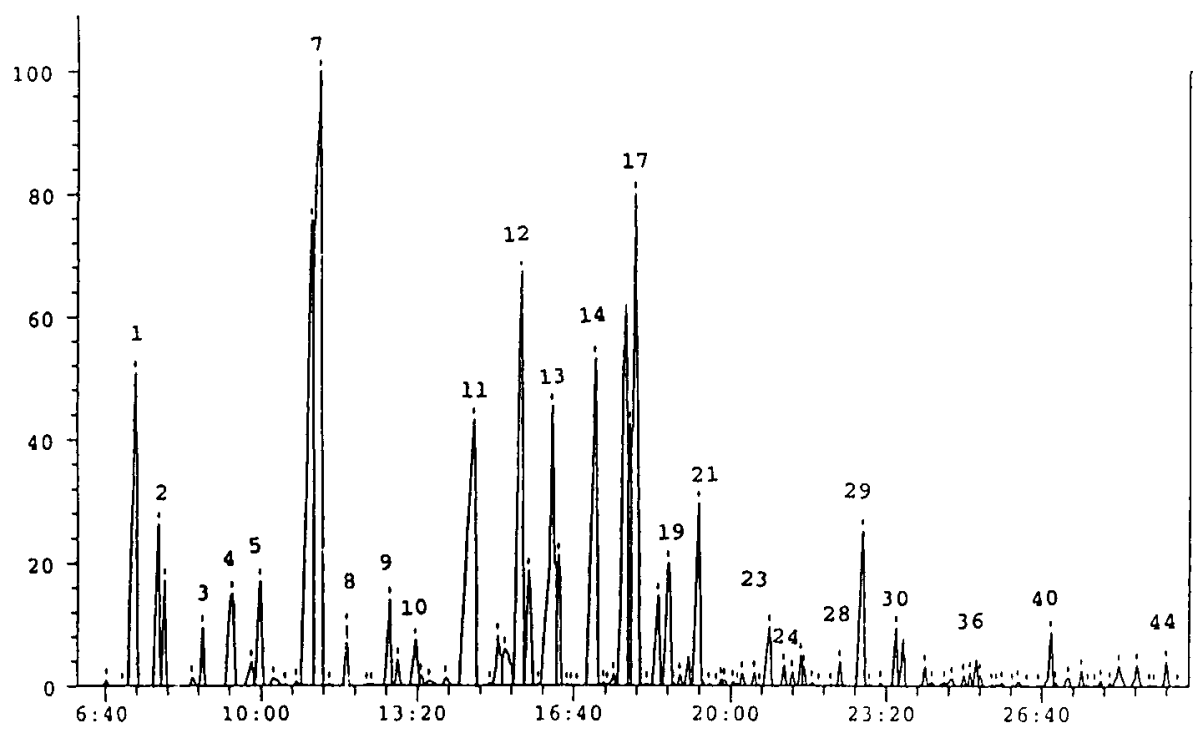

Fig. 2. Chromatogram of rosemary oil

Data in Tables 1, 2, 3 show that forty-six compounds of sweet marjoram could be identified representing about $93.3 \%$ of the total content. It is evident that about $53 \%$ of the total oil consisted of terpene hydrocarbons with $\gamma$-terpinene accounting about $21.5 \%$ of total oil, sabinene $+\beta$-pinene and p-cymene represented about $14 \%$ and $7.8 \%$ of total oil content, respectively. The oxygenated terpenes contributed with $36.48 \%$ of the oil content, terpineol- 4 and $\alpha$-terpineol represented about $8.2 \%$ and $6.2 \%$ of the total oil content, respectively. On the other hand sesquiterpenes and oxygenated sesquiterpenes represented about $8 \%$ and $2.6 \%$ of the oil content respectively.

\section{Repellency and oviposition deterrence}

In $T$. urticae, percent repellency gradually increased with both essential oil concentrations (Table 4). On the contrary, rosemary oil proved to be completely deterrent for E. orientalis even after $72 \mathrm{~h}$, of treatment and at the lowest concentrations (Table 5). Repellency of sweet marjoram oil decreased at $0.125 \%$ conc. in comparison with other concentrations (Table 5). As for oviposition behavior [Oviposition deterrent indices (ODI) as defined by Lundgren 1975] in case of E. orientalis, both oils hindered adults to lay eggs except at $0.125 \%$ conc. of sweet marjoram (Table 5). The average number of eggs laid by females of T. urticae after $72 \mathrm{~h}$ of treatment varied according to concentrations (Table 4). Mansour et al. (1986) found that bean leaf discs sprayed with concentrations of the acetonic solutions of the rosemary oil from $0.1 \%$ to $2 \%$ caused mortality and induced repellency to $T$. cinnabarinus (Boisd) within $48 \mathrm{~h}$ of placing adult females on the discs and consequently egg-laying was reduced. Mazeed (1987) demonstrated that marjoram oil form 
(Origanum majorana) was effective for controlling the spread of Acaropis woodi (Rennie) to young workers introduced to infested colonies. Both rosemary and sweet marjoram oils gave $100 \%$ repellency to T. urticae at $10 \%$ level of concentration (Sawires et al., 1988).

The varying effect of the different oils may be due to the varying constituents of oxidative substances within the solid part of the volatile oil.

\section{Table 4}

Relative distribution and oviposition of T. urticae on treated leaf discs with rosemary and sweet marjoram oils

\begin{tabular}{|c|c|c|c|c|c|c|c|}
\hline \multirow[t]{3}{*}{$\begin{array}{c}\% \\
\text { concentrations }\end{array}$} & \multicolumn{3}{|c|}{$\begin{array}{c}\% \text { distribution } \\
\text { on treated part after }\end{array}$} & \multirow[t]{3}{*}{$\begin{array}{c}\% \\
\text { repellency }\end{array}$} & \multirow{2}{*}{\multicolumn{2}{|c|}{$\begin{array}{l}\begin{array}{l}\text { Avg. No. of } \\
\text { eggs/female }\end{array} \\
\text { after } 72 \mathrm{~h}\end{array}$}} & \multirow[t]{3}{*}{ ODI } \\
\hline & & & & & & & \\
\hline & $24 \mathrm{~h}$ & $48 \mathrm{~h}$ & $72 \mathrm{~h}$ & & $\mathrm{~T}$ & C & \\
\hline \multicolumn{8}{|c|}{ Rosemary } \\
\hline 2 & 15 & 20 & 30 & 91 & 0.15 & 1.65 & 83.33 \\
\hline 1 & 15 & 25 & 30 & 89.5 & 0.2 & 1.9 & 80.95 \\
\hline 0.5 & 25 & 30 & 35 & 82.1 & 0.35 & 1.95 & 69.57 \\
\hline 0.25 & 35 & 35 & 50 & 67.3 & 0.9 & 2.75 & 50.68 \\
\hline 0.125 & 40 & 50 & 80 & 46.6 & 1.55 & 2.9 & 30.34 \\
\hline \multicolumn{8}{|c|}{ Sweet marjoram } \\
\hline 2 & 5 & 5 & 5 & 100 & 0 & 0.7 & 100 \\
\hline 1 & 10 & 10 & 15 & 100 & 0 & 0.7 & 100 \\
\hline 0.5 & 15 & 20 & 25 & 92.5 & 0.2 & 2.65 & 85.96 \\
\hline 0.25 & 15 & 25 & 30 & 85.5 & 0.4 & 2.75 & 74.60 \\
\hline 0.125 & 20 & 25 & 40 & 69.6 & 0.85 & 2.8 & 53.42 \\
\hline
\end{tabular}

$\mathrm{C}=$ control; $\mathrm{T}=$ treated

\section{Table 5}

Relative distribution and oviposition of E. orientalis on treated leaf discs with rosemary and sweet marjoram oils

\begin{tabular}{|c|c|c|c|c|c|c|c|}
\hline \multirow[t]{3}{*}{$\begin{array}{c}\% \\
\text { concentrations }\end{array}$} & \multicolumn{3}{|c|}{$\begin{array}{c}\% \text { distribution } \\
\text { on treated part after }\end{array}$} & \multirow[t]{3}{*}{$\begin{array}{c}\% \\
\text { repellency }\end{array}$} & \multirow{2}{*}{\multicolumn{2}{|c|}{$\begin{array}{c}\begin{array}{c}\text { Avg. No. of } \\
\text { eggs/female }\end{array} \\
\text { after } 72 \mathrm{~h}\end{array}$}} & \multirow[t]{3}{*}{ ODI } \\
\hline & & & & & & & \\
\hline & $24 \mathrm{~h}$ & $48 \mathrm{~h}$ & $72 \mathrm{~h}$ & & $\mathrm{~T}$ & $\mathrm{C}$ & \\
\hline \multicolumn{8}{|c|}{ Rosemary } \\
\hline 2 & 0 & 0 & 0 & 100 & 0 & 0 & 0 \\
\hline 1 & 0 & 0 & 0 & 100 & 0 & 0.25 & 100 \\
\hline 0.5 & 0 & 0 & 0 & 100 & 0 & 0.35 & 100 \\
\hline 0.25 & 0 & 0 & 0 & 100 & 0 & 0.45 & 100 \\
\hline 0.125 & 0 & 0 & 0 & 100 & 0 & 0.45 & 100 \\
\hline \multicolumn{8}{|c|}{ Sweet marjoram } \\
\hline 2 & 0 & 0 & 0 & 100 & 0 & 0.65 & 100 \\
\hline 1 & 0 & 0 & 0 & 100 & 0 & 1.25 & 100 \\
\hline 0.5 & 5 & 0 & 5 & 100 & 0 & 1.45 & 100 \\
\hline 0.25 & 5 & 5 & 5 & 100 & 0 & 2.7 & 100 \\
\hline 0.125 & 25 & 25 & 25 & 90.8 & 0.25 & 2.7 & 83.05 \\
\hline
\end{tabular}

$\mathrm{C}=$ control; $\mathrm{T}=$ treated 


\section{Concentration effects on oviposition and mortality}

Significant reduction in the total number of eggs laid by both tetranychid mites were recorded during 10 days period for all concentration tested for both essential oils (Table 6). Fecundity was severely reduced as the concentration of both oils increased. Previous studies have shown that the essential oils of Callistemon lanceolatus DC. and

\section{Table 6}

Effect of rosemary and sweet marjoram oils on reproduction and mortality of T. urticae and E. orientalis

\begin{tabular}{|c|c|c|c|c|}
\hline \multirow{2}{*}{$\begin{array}{l}\text { Conc. } \\
\%\end{array}$} & \multicolumn{2}{|c|}{ Rosemary } & \multicolumn{2}{|c|}{ Sweet marjoram oil } \\
\hline & $\begin{array}{c}\text { Total No. of } \\
\text { eggs/female/10 days** }\end{array}$ & $\begin{array}{c}\% \text { corrected mortality } \\
\text { after } 10 \text { days }^{*}\end{array}$ & $\begin{array}{c}\text { Total No. of } \\
\text { eggs/female/10 days** }\end{array}$ & $\begin{array}{c}\% \text { corrected mortality } \\
\text { after } 10 \text { days }^{*}\end{array}$ \\
\hline & \multicolumn{4}{|c|}{ T. urticae } \\
\hline 2 & 1.75 & 53.85 & 0.25 & 90.91 \\
\hline 1 & 2.10 & 15.38 & 3.25 & 27.27 \\
\hline 0.5 & 6.50 & 8.33 & 4.80 & 25.00 \\
\hline 0.25 & 6.90 & 7.69 & 10.20 & 23.10 \\
\hline 0.125 & 13.10 & 7.14 & 17.15 & 21.43 \\
\hline \multirow[t]{2}{*}{ Control } & 58.5 & - & 58.5 & - \\
\hline & \multicolumn{4}{|c|}{ E. orientalis } \\
\hline 2 & 0 & 100 & 0 & 100 \\
\hline 1 & 0 & 100 & 0.20 & 100 \\
\hline 0.5 & 1.10 & 71.43 & 0.50 & 92.86 \\
\hline 0.25 & 1.50 & 60.00 & 1.90 & 86.67 \\
\hline 0.125 & 2.35 & 60.00 & 2.30 & 80.00 \\
\hline Control & 15.4 & - & 15.4 & - \\
\hline
\end{tabular}

${ }^{*}$ Counts according to Abbott's Formula (1925).

${ }^{* *}$ Highly significantly at $\mathrm{P}<0.01$

[statistical analysis based on Least Significant Difference (L.S.D. test)]

Cotula cinerea $\mathrm{L}$. had deterrent effects on females of T. urticae and spraying females with $\mathrm{LC}_{50}$ significantly reduced its fecundity (Ibrahim and Amer, 1992; Ibrahim et al., 1993). However, percentage mortality was significantly concentration dependent. In case of $E$. orientalis at $2 \%$ and $1 \%$ conc. it was high with both oils and reached $100 \%$ with T. urticae the trend was similar albeit at a slightly lower rate increasing from 7.14 and $21.43 \%$ to 53.85 and $90.91 \%$ with rosemary and sweet marjoram, respectively. The results clearly depended on the mite used for experiments, as marked differences in mortality were recorded. Amer et al. (1993) reported that the orange peel oil showed a remarkable deterrent effect with E. orientalis, whereas the essential oil of lemon grass in addition to the orange peel oil was toxic to females and eggs of T. urticae and E. orientalis. Regnault and Hamraoui (1995) suggested that lipid as well as non-lipid allelochemicals, such as phenolics, or non-protein amino acids or flavonoids, may be involved in the toxicity of extracts of aromatic plant $R$. officinalis and Eucalyptus globulus to Acanthoscelides obtectus. El Gengaihi et al. (1992) confirmed the role of volatile oil as having antifeedant and growth 
inhibiting effects of Vitex agnus costus on Spodoptera littoralis larva. Rosemary and sweet marjoram oils were promising for possible use against $T$. urticae and E. orientalis. It is worth mentioning that oils with such properties will not disturb ecosystems and consequently, will not cause outbreaks of new pests, as persistent insecticides are apt to do.

\section{Literature}

Adams, R. A. (1989): Identification of essential oils by ion trap mass spectroscopy. Academic Press, Inc., New York.

Amer, S. A. A. (1984): Biological, ecological and toxicological studies on the common spider mite Tetranychus arabicus in Egypt. Ph.D. thesis, Fac. of Agric., Cairo University.

Amer, S. A. A., Abou-Awad, B. A. and El- Banhawy, E. M. (1993): Toxicity of the orange peel and lemon grass oils to the spider mites Tetranychus urticae and Eutetranychus orientalis with effects on the development and reproduction (Acari: Tetranychidae). Afr. J. Agric. Sci. 20, 95-102.

Amer, S. A. A., Reda, A. S. and Dimetry, N. Z. (1989): Activity of Abrus precatorius L. extracts against the twospotted spider mite Tetranychus urticae Koch (Acari: Tetranychidae). Acarologia 30, 209-215.

Arnason, J. T., Philogene, B. J. R. and Morand, P. (eds) (1989): Insecticides of plant origin. Amer. Chem. Soc. Symp. Series No. 387, Amer. Chem. Soc., Washington, DC, 213 pp.

Dimetry, N. Z., El-Gengaihi, S., Reda, A. S. and Amer, S. A. A. (1990): Toxicity of some compounds isolated from Abrus precatorius L. seeds towards the two spotted spider mite Tetranychus urticae Koch. Acarologia 31, 366.

Don-Pedro, K. N. (1985): Toxicity of some citrus peels to Dermestes maculatus Deg. and Callosobruchus maculatus (F). J. stored Prod. Res. 81, 31.

El-Gengaihi, S., Amer, S. A. A. and Mohamed, S. M. (1992): Biological activity of Peganum harmala L. extracts towards the two spotted spider mite Tetranychus urticae Koch (Acari: Tetranychidae). Annals Agric. Sci. Moshtohar 31, 1213-1220.

El-Gengaihi, S., Amer, S. A. A. and Mohamed, S. M. (1996): Biological activity of Thyme oil and Thymol against Tetranychus urticae Koch. Anz. Schad. Pflan., Umw. 69, 157-159.

Guenther, E. (1961): The Essential Oils. D. Van Nostrand Comp. Inc. Toronto, London, pp. 520-525 and 708-710.

Ibrahim, M. E. and Amer, S. A. A. (1992): Chemical and acaricidal studies on the essential oil of Callistemon lanceolatus, DC. plant grown in Egypt. J. Appl. Sci. 7, 445-456.

Ibrahim, M. E., Abouzeid, A. H., Awad, N. E. and Amer, S. A. A. (1993): The essential oil and some extracts of Cotula cinerea L. and their biological activity on Tetranychus urticae. Egypt. J. Appl. Sci. 8, 1-14.

Lwande, W., Hassanali, P. W., Njoroge, P. W.; Bentely, M. D., Delle Monache, F. and Jondiko, J. I. (1985): A new 6, a-hydroxy pterocarpon with insect antifeedant and antifungal properties from the roots of Tephrosia hildebrantii Vatke. Insect. Sci. Applic. 6, 537-547.

Mansour, F., Ravid, U. and Putievsky, E. (1986) : Studies of the effects of essential oils isolated from 14 species of labiatae on the carmine spider mite, Tetranychus cinnabarinus. Phytoparasitica 14, 137-142.

Mazeed, M. M. (1987): Controlling acarine mites with natural materials. Gleanings-in-Bee-culture 115, 517-520.

Purohit, P., Mustafa, M. and Osmani, Z. (1983): Insecticidal properties of plant-extract of Cumminum cyminum linn. Science and culture 4, 101-107.

Rasmy, A. H. (1985): The biology of the two-spotted spider mite Tetranychus urticae as affected by resistant solanaceous plants. Agric. Ecosyst. Environ. 13, 325-328.

Regnault, R. C. and Hamraoui, A. (1995): Comparison of the insecticidal effects of water extracted and intact aromatic plants on Acanthoscelides obtectus, a bruchid beetle pest of kidney beans. Chemoecology 6, 1-5.

Sawires, Z. R., El-Halawany, M. and Nassar, M. (1988): Response of Tetranychus urticae Koch to some naturally active products. Bull. Zool. Soc., Egypt. 36, 42-45. 
Schauer, M. and Schmutterer, H. (1981): Effect of neem kernel extracts on the two spotted spider mite, Tetranychus urticae. Proc. 1st Int. Neem Conf. (Rottach-Egern, 1980), 259-266.

Sy, H. C. F., Spenrs, R. D. and Mahany, P. G. (1972): Toxicity of citrus oils to several stored-product insectlaboratory evaluations. J. Econ. Ent. 65, 1438.

Tare, V. and Sharma, R. N. (1988): Antifeedant action of some oils and their constituents on some agriculture pests. Proc. Nat. Symp. on Integr. Pest Control Progress and Prospective. (eds): Mohandas and G. Koshy, Trivandrum, 450-452. 